\title{
Strategic orientations and cooperation of external agents in the innovation process of rural enterprises
}

\author{
As orientações estratégicas e a cooperação dos agentes \\ externos no processo de inovação das empresas rurais \\ José Francisco dos Reis Neto ${ }^{I^{*}}$ Pablo Antonio Muñoz-Gallego ${ }^{\text {II }}$ \\ Celso Correia de Souza ${ }^{I}$ Denise Renata Pedrinho ${ }^{I}$ \\ Silvio Favero ${ }^{I}$ Alex Sandro Richter von Mühlen ${ }^{\text {III }}$
}

\section{ABSTRACT}

This article provides empirical evidence for the relationship between the market orientation, entrepreneurial orientation, and collaboration of external actors in the processes of incremental and radical innovations in rural enterprises. The research tested two sets of assumptions: first, the relation between contributions of strategic orientation and innovation processes, and second, collaborations of external stakeholders in the implementation of innovation processes. Data were collected from 208 rural enterprises and analyzed with the use of techniques of partial least squares structural equation modeling. Results showed that the market orientation contributes to the development of incremental innovation, and that the entrepreneurial orientation contributes to the implementation of the incremental and radical innovations. Specific agents (buyers, suppliers of goods and services, consultants, and others producers), collaborate positively in implementing incremental innovation; however, generic agents do not. The generic agents (universities and specialized public organizations) are the ones that most intervene in radical innovations. The use of consistent theory in the areas of strategy marketing and management in identifying that some of their causal relationships are confirmed for rural businesses unlike others, due to the structure of the market and the products produced by them.

Key words: market orientation, entrepreneurial orientation, incremental innovation, radical innovation, specific agents, generic agents, rural firms.

\section{RESUMO}

Este artigo fornece evidências empiricas sobre as relações entre a orientação para o mercado, a orientação empreendedora e a colaboração dos agentes externos nos processos de inovações incrementais e radicais em empresas rurais. A pesquisa testou três conjuntos de hipóteses: no primeiro, relacionaram-se as contribuições das orientações estratégicas e os processos de inovação; no segundo, verificaram-se as colaborações dos agentes externos na implementação dos processos de inovação $e$, no terceiro, avaliaram-se os efeitos de moderação do ambiente e da intensidade competitiva no relacionamento entre as orientações estratégicas e os processos de inovações. Os dados foram coletados em 208 empresas rurais e analisados com o emprego de técnicas da modelagem de equações estruturais pelo método de mínimos quadrados parciais. Os resultados mostram que a orientação para o mercado contribui para o desenvolvimento da inovação incremental, e que a orientação empreendedora contribui na implementação das inovações incrementais e radicais. Os agentes especificos (compradores, fornecedores de bens e serviços, consultores e outros agricultores), colaboram positivamente na execução da inovação incremental, mas os agentes genéricos, não. Os agentes genéricos (universidades e organizações públicas) são as que intervêm mais na inovação radical. Destaca-se a utilização de teoria consistente na área de estratégia, marketing e gestão na identificação de que algumas das suas relações causais são confirmadas para as empresas rurais, e outras não, em decorrência da estrutura, do mercado e dos produtos produzidos por elas.

Palavras-chave: orientação para o mercado, orientação empreendedora, inovação incremental, inovação radical, agentes específicos, agentes genéricos, empresa rural.

\section{INTRODUCTION}

The agribusiness has witnessed a major change in the requirements related to its production.

\footnotetext{
'Programa de Pós-graduação em Produção e Gestão Agroindustrial, Universidade Anhanguera (UNIDERP), Rua Alexandre Herculano, 1400, 79037-280, Campo Grande, MS, Brasil. E-mail: jfreisneto@uniderp.edu.br. *Corresponding author.

"Instituto Multidisciplinar de la Empresa, University of Salamanca - España, Campus Miguel de Unamuno, Edificio FES, 37007 Salamanca, Spain.

IIIUniversidade Estadual de Mato Grosso do Sul (UEMS), Dourados, MS, Brasil. 
Local and international context exert pressure and induces changes in different sectors of the economy, specifically in agriculture and livestock, leading to improved use of resources and productive capacities. Rural enterprises must understand that its primary sector is integrated into the agribusiness as a link of production to other sectors related to inputs and services suppliers, buyers, distributors, research and development entities as well as end users. The required changes in production, modernization and development of the rural enterprise establish the need for the company to have the knowledge and ability to incorporate innovations.

The primary justification of the development of this study is due to the important role of rural enterprises for the Brazilian economy in the last two decades (BRUGNARO \& BACHA, 2009). According to CEPEA (2015), the participation of rural enterprises represents $22-23 \%$ of gross domestic product (GDP), with a $68 \%$ share in agriculture, $32 \%$ share in livestock, and 35\% share in labor; standing out as one of the leading players in the global food trade. The second justification for this study is due to the few empirical studies that exist on the process of innovation in agricultural companies (JOHNSON et al., 2009).

In this situation, two research questions are proposed to agricultural enterprises: 1) Does the adopted strategic orientation contribute to the development of the innovation process? 2) What is the external agent's (specific or generic) form of collaboration in the innovation process?

\section{MATERIALS AND METHODS}

Innovation in a company establishes an interactive process sustained by the perception of market needs or arising demands gathered from new business opportunities. The enterprise obtains innovations by introducing products and services that bring more satisfaction to the needs of buyers; who recognize the differences between the new product or service and the old one. The innovation is also related to the use of field research, experimentation, imitation, adoption of new products, new production processes and new organizational structures within the company (HUNTER, 2013). In this research, the innovation was classified in incremental or radical. Incremental innovation (II) is small changes made to the basis of management or technology of the rural enterprise as an improvement in the benefits achieved to meet the needs and desires of buyers. These changes cause simplifications and improvements of certain business dimensions highlighted in the production processes as well as products and services offered, which meet the specific needs of the company and its surroundings. Thus, within the rural business, it is sought to obtain improvement in efficiency and productivity (VALLE \& VAQUEZ, 2009). The radical innovation (RI) is defined as the set of actions that alter or modify drastically the processes, products and services. It involves new knowledge and new sources of raw materials that improve business performance, and the creation of a new business (NAMAN \& SLEVIN, 1993). In this study, it was considered the radical innovation of a rural enterprise as creating a new business, understood as the acquisition of a new rural property that serves new products, new buyers or emerging markets.

Strategic orientations are the organization's actions to meet the demands required by the market, the competition and buyers; responding with its resources and competitive capabilities, and taking advantage of opportunities that arise to provide new processes and new products. Two strategic concepts are presented in this research, focusing on market orientation (MO) and entrepreneurial orientation (EO). The MO is a solid business strategy that seeks to improve efficiency and effectiveness. This strategic process collects information related to the interests, needs and desires of both existing and potential buyers, and assesses the actions and movements of competitors within the sector; using this in the crossfunctional coordination of the business to enable it to respond to exogenous factors (NARVER \& SLATER, 1990). The activity developed by the rural business under the MO strategy, continuously evaluates the processes and behaviors of the market and the buyers. Considering the various studies presented regarding the $\mathrm{MO}$ as a way of integrating the company's strategy towards the innovations in their processes and products (JOHNSON et al., 2009), the following hypothesis was proposed:

H1: Market orientation (MO) contributes positively to the development of (a) incremental innovation (II) and (b) radical innovation (RI).

Entrepreneurial orientation (EO) is the adoption of strategies defined by the company, engaged in the innovation of products, processes and markets. These business strategies are based on the willingness of the company to take necessary risks for the process of change and innovation as a competitive advantage, by adopting a proactive posture (COVIN \& SLEVIN, 1991). The referenced authors stated that these entrepreneurial dimensions 
cause interventions in the management model of the company, transforming the administration and management processes in such a way that the competitive and creative actions are reflected in order to reach a prominent position compared to competitors (RAUCH et al., 2009). Decision-making, and practices and processes derived from the entrepreneurial orientation, can lead to the intentional creation of new businesses, suggesting the following assumptions:

$\mathrm{H} 2$ : Entrepreneurial orientation (EO) contributed positively to the development of (a) incremental innovation (II) and (b) radical innovation (RI).

The innovation process in rural businesses poses challenges to improve the products and services offered, assuming that this process requires the development of capabilities to respond with agility and flexibility to changes and to the environmental turmoil in which it operates (TIDD \& BESSANT, 2009). It is very difficult for a rural business, especially one already established in the market, to innovate in isolation since it depends on internal and external contributions and requirements. The uncertainty of the innovation process leads rural firms to utilize the help, experience and knowledge from external sources, so that these can collaborate in the increased efficiency of the innovative process using a positioning strategy that will guarantee a better business performance and generate sustainable competitive advantages developed with unique resources and capabilities (GELLYNCK et al., 2014).

Specific agents (SA) are buyers, input suppliers (shops, manufacturers, and sellers), and consultants (agricultural technicians, veterinarian, and agronomists) and other similar producers of agriculture. Consequently, the cooperation of external agents increases the chances of development for the innovation process. Thus, the following hypothesis is proposed for SA:

H3: Specific agents (SA) collaborate positively to (a) the incremental innovation process (II) and (b) radical innovation (RI) of a rural business. Generic agents (GA) are external sources from which rural businesses acquire the knowledge of the new method or the process to improve the production of a new technology, or a new market. Both processes, related to their agricultural activities, considered as essential resources in order to increase production efficiency (JOHANNESSEN et al., 2001), are important factors for the implementation of the incremental or radical innovation process. The basic operating characteristics of rural enterprises in the use of its resources and capabilities in agricultural production, does not lead directly to research and development of management and technology. To address these gaps, the business turn to institutions that supply or support the agricultural innovations and act as actors of rural development, such as industry unions, government agencies that provide rural assistance, and universities (ZUIN \& QUEIROZ, 2006). For GA, the following assumptions is suggested:

H4: Generic agents (GA) collaborate positively to (a) the incremental innovation process (II) and (b) the radical innovation (RI) of a rural business.

Based on literature and according to the suggested causal relationships, the reflectiveformative theoretical model of second order (Figure 1) was presented, with the representation of the latent variables without the representation of the observed reflective items.

The survey technique for data collection through a questionnaire was applied, with components statements of all latent variables used in this study (Table 1). It also included the identification of the demographic characteristics of rural enterprises. All the items of latent variables of the structural model were measured by using the Likert scale of seven points, in which the value 1 is the weakest/ lowest concept of the assessed amount, importance or agreement, and the value 7 being the strongest/ highest. The survey was then applied directly to the owners and managers from February to April 2014. Data was collected from 208 questionnaires in Mato Grosso do Sul State; the items were related to their latent variables and their unidimensionalities were verified; i.e. if each of them could be represented by the exploratory factor analysis with varimax rotation method was employed, using the SPSS v. 23 software. As a result, the adjusted theoretical model, with a reflective-formative type, was tested through the resolution of the by partial least squares

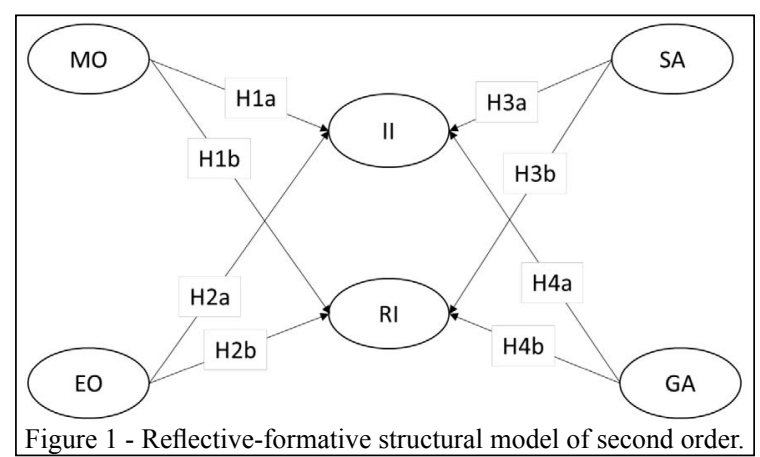

Ciência Rural, v.46, n.10, out, 2016. 
Table 1 - Measures of communalities and reliability indicators of latent variables and its items.

\begin{tabular}{|c|c|c|}
\hline Latent variable (reference) & Items & Com \\
\hline \multirow{6}{*}{ Incremental Innovation (II) (WANG \& AHMED, 2004) } & Q15a Strategy & 0.62 \\
\hline & Q15b Management & 0.71 \\
\hline & Q15c Organization & 0.69 \\
\hline & Q15d Marketing & 0.57 \\
\hline & Q15e Production processes & 0.64 \\
\hline & Q15f Product & 0.56 \\
\hline
\end{tabular}

$\mathrm{KMO}=0.88 ;$ Bartlett $=617.32, \mathrm{p}=0.001 ; \mathrm{MSA}=0.84 ; \mathrm{ev}=63.30 \% ; \alpha=0.88$

Radical Innovation (RI) (NAMAN \& SLEVIN, 1993)

Q19g Creation of new businesses

Only one item (no indicators are available)

Q19a Launch of new agricultural products

$\mathrm{KMO}=0.87 ;$ Bartlett $=756.98, \mathrm{p}=0.001 ; \mathrm{MSA}=0.82 ; \mathrm{ev}=68.50 \% ; \alpha=0.91$

Q20a Market information $\quad 0.65$

Q20b Competitors' strategies information $\quad 0.54$

Q20c Customer satisfaction information $\quad 0.71$

Market Orientation (MO) (NARVER \& SLATER, 1990) Q20d Structure and trends of rural market $\quad 0.72$ Q20e Internal discussion regarding trends of the rural market $\quad 0.59$ Q20f Complaints and suggestions from buyers 0.61 Q20g Analysis of environment anticipation and change $\quad 0.67$

$\mathrm{KMO}=0.85 ;$ Bartlett $=836.84, \mathrm{p}=0.001 ; \mathrm{MSA}=0.76 ; \mathrm{ev}=64.30 \% ; \alpha=0.91$

Q16a Suppliers or manufacturers $\quad 0.59$

Q16b Buyers and customers 0.77

Specific Agents (SA) (ZUIN \& QUEIROZ, 2006)

Q16C Competitors or other producers $\quad 0.58$

Q16d Agribusiness Consultants $\quad 0.59$

$\mathrm{KMO}=0.76 ;$ Bartlett $=270.80, \mathrm{p}=0.001 ; \mathrm{MSA}=0.70 ; \mathrm{ev}=63.10 \% ; \alpha=0.80$

Q16f Agribusiness Federation $\quad 0.66$

Q16g Agricultural Industry Federation $\quad 0.71$

Generic Agents (GA) (ZUIN \& QUEIROZ, 2006)

Q16h Small Business support service $\quad 0.79$

Q16i Agricultural State Bureau $\quad 0.73$

Q16j Agency Rural Extension $\quad 0.74$

Q16k Use of University facilities and services $\quad 0.54$

$\mathrm{KMO}=0.91 ;$ Bartlett $=795.30, \mathrm{p}=0.001 ; \mathrm{MSA}=0.90 ; \mathrm{ev}=69.80 \% ; \alpha=0.91$

Legend (critical value): Com - Communality $(>0.50)$; KMO - Kaiser-Meyer-Olkin test $(>0.50)$; Bartlett - Bartlett sphericity test ( $<<0.05)$; MSA - measure sampling adequacy $(>0.50)$; ev - explained variance ( $>50 \%) ; \alpha$-Cronbach's alpha reliability measure $(>0.70)$. 
structural equation modeling (PLS-SEM) method, using the SmartPLS 2.0 software.

\section{RESULTS AND DISCUSSION}

The database collected in 45 out of the 79 existing municipalities in Mato Grosso do Sul, from 61,664 agricultural establishments (IBGE, $2009)$. For the respondents, $48.6 \%$ explore a rural area between 100 and 1,500 hectares, $31.7 \%$ are small rural enterprises, $28.4 \%$ are medium rural enterprises, and $41.8 \%$ are large rural enterprises. In terms of employees in rural business, $74.9 \%$ have up to nine employees, $51.2 \%$ have no employees with university education, and $68.8 \%$ work in the livestock sector. Due to the high participation of shareholders/owners of rural enterprises (71.5\%) in response to the questionnaires, the quality of the assessments performed and the strategic guidelines adopted can be considered as a relevant fact, as well as the relationship between external agents and rural business, and the perception of turbulence in the business environment.

To confirm the validity of the factorial relationship between the latent variables and its items, exploratory factor analysis with varimax rotation was performed using the SPSS v.23; removing from the initial model the items that did not meet the assumptions of communality $\geq 0.50$. Table 1 shows the results of the adjusted model with indicators higher than the reference values proposed by HAIR et al. (2014), leading to a reflective measurement model of latent variable with its items at a one-dimensional form for $\mathrm{MO}, \mathrm{EO}, \mathrm{SA}$, RI, II and RI. Reflective-formative theoretical model of second order (Figure 1) was processed with the use of SmartPLS 2.0. Table 2 provides the evidence to accept the discriminant validity, the convergent validity of the model by means of the average variance extracted, the internal consistency by means of composite reliabilities, and the values of Cronbach's alpha. Thus, the adjusted model was accepted as adequate and the collected sample is considered reliable to represent it. Portions of the variance explained for the exogenous variables II and RI are moderate, considering values of the coefficients of determination $\left(\mathrm{R}^{2}\right)$ and the quality of predictive relevance $\left(\mathrm{Q}^{2}\right)$ is average for II and high for RI (HAIR et al., 2014). These results reinforce the importance of the latent variables II and RI for the model. Next, by accepting the consistency of the adjusted theoretical model it was verified the proposed hypotheses; evaluating the values of $t$ statistics for the path coefficients at $\mathrm{P}<0.05$, indicated in table 3 .

Adoption of MO strategy positively influenced the II process, accepting hypothesis H1a. The result confirmed the theoretical assumptions of $\mathrm{MO}$ as a continuous improvement strategy, enabling lower costs and improving the quality of processes and products, in order to obtain more efficient business performance and a more effective value creation offer for the buyer (NARVER \& SLATER, 1990). Orientation for the buyer and for the competitor, as well as the cross-functional coordination, is reported as positive in order to rural business to implement its incremental innovation process. Similar results were reported in studies of rural enterprises focusing in the international market and in the local market (RUVIARO et al., 2014) . Causal relationship between MO and RI leads to the rejection of hypothesis $\mathrm{H} 1 \mathrm{~b}$. The MO of rural business when considering achieving a higher and continuous performance, determines the direction of their efforts towards the product and process (KUMAR et al., 2011), presenting less strategic commitments to the deep, irregular, discontinuous and uncertain changes, as required by the radical innovation (ZUIN \& QUEIROZ, 2006). The EO contributes to the

Table 2 - Discriminant validity between the latent variables and quality of adjustment of the adjusted model.

\begin{tabular}{|c|c|c|c|c|c|c|c|c|c|c|c|}
\hline \multirow{2}{*}{ Latent variable } & \multicolumn{6}{|c|}{ 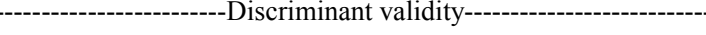 } & \multirow[b]{2}{*}{ AVE } & \multirow[b]{2}{*}{$\mathrm{CR}$} & \multirow[b]{2}{*}{$\mathrm{R}^{2}$} & \multirow[b]{2}{*}{$\mathrm{Q}^{2}$} & \multirow[b]{2}{*}{$\alpha$} \\
\hline & SA & GA & II & RI & EO & MO & & & & & \\
\hline SA & 0.79 & & & & & & 0.63 & 0.87 & & & 0.80 \\
\hline GA & 0.58 & 0.81 & & & & & 0.65 & 0.93 & & & 0.91 \\
\hline II & 0.39 & 0.35 & 0.79 & & & & 0.62 & 0.91 & 0.44 & 0.27 & 0.88 \\
\hline RI & 0.24 & 0.30 & 0.48 & One item & & & 1.00 & 1.00 & 0.36 & 0.37 & 1.00 \\
\hline EO & 0.32 & 0.41 & 0.58 & 0.60 & 0.81 & & 0.66 & 0.92 & & & 0.89 \\
\hline MO & 0.42 & 0.49 & 0.59 & 0.44 & 0.63 & 0.79 & 0.63 & 0.92 & & & 0.90 \\
\hline
\end{tabular}

Note: Values on the diagonal in bold correspond to the extracted square root of the average variance extracted (AVE).

Legend: CR - composite reliability; $\mathrm{R}^{2}$ - coefficient of determination; $\mathrm{Q}^{2}$ - predictive validity; $\alpha$ - Cronbach's alpha reliability measurement. 
Table 3 - Hypotheses, results and significance levels of the adjusted model.

\begin{tabular}{|c|c|c|c|c|c|}
\hline Path & Hypothesis & Path coefficient & Standard deviation & $t$ & Conclusion \\
\hline $\mathrm{MO}->\mathrm{II}$ & $\mathrm{H} 1 \mathrm{a}$ & 0.33 & 0.08 & $4.03^{*}$ & Accepted \\
\hline MO -> RI & $\mathrm{H} 1 \mathrm{~b}$ & 0.09 & 0.09 & 0.96 & Rejected \\
\hline $\mathrm{EO}->\mathrm{II}$ & $\mathrm{H} 2 \mathrm{a}$ & 0.35 & 0.07 & $4.88^{*}$ & Accepted \\
\hline $\mathrm{EO}->\mathrm{RI}$ & $\mathrm{H} 2 \mathrm{~b}$ & 0.52 & 0.08 & $6.36^{*}$ & Accepted \\
\hline SA -> II & $\mathrm{H} 3 \mathrm{a}$ & 0.17 & 0.07 & $2.37^{*}$ & Accepted \\
\hline $\mathrm{SA}->\mathrm{RI}$ & $\mathrm{H} 3 \mathrm{~b}$ & 0.01 & 0.08 & 0.07 & Rejected \\
\hline GA -> II & $\mathrm{H} 4 \mathrm{a}$ & -0.05 & 0.07 & 0.69 & Rejected \\
\hline GA $->$ RI & $\mathrm{H} 4 \mathrm{~b}$ & 0.04 & 0.07 & 0.61 & Rejected \\
\hline
\end{tabular}

Legend: Two-tailed significance level: ${ }^{*} \mathrm{P}<0.001$.

development of innovative processes (II and RI), accepting hypotheses $\mathrm{H} 2 \mathrm{a}$ and $\mathrm{H} 2 \mathrm{~b}$ (Table 3 ). This is sustained when it appears that the EO causes changes in management processes and production methods, incorporated in II (RAUCH et al., 2009). In addition, when the rural company adopts proactive strategies to create new products and new markets using EO, it strengthens the development of RI.

The SA such as suppliers of equipment and inputs, buyers of rural production, and other rural companies in the same productive sector, can collaborate in the process of II. This fact can be deduced from the results shown in table 3, accepting hypothesis H3a. In addition, according to table 3 , SA did not collaborate with the RI process, rejecting hypothesis H3b. The SA act as employees of rural enterprises in management and technology incremental innovation, improving elements of efficiency and productivity, as revealed by VALLE \& VAQUEZ (2009). On the contrary, due to failure in obtaining significant evidence of causal relationship, theseagentsdonotcollaborate in theprocesses of RI. Since rural enterprises have limited resources and capacities, which are directed to agricultural production, it was assumed that the process of II and RI could use the collaboration of GA. The path coefficients, $t$ statistics and the significance levels obtained in table 3 allowed the rejection of hypotheses $\mathrm{H} 4 \mathrm{a}$ and $\mathrm{H} 4 \mathrm{~b}$. Empirical evidence infers that rural businesses use some development agents (associations, unions, government agencies and universities) as a resource for agricultural innovations; a fact that confronts the ideas of JOHANNESSEN et al. (2001) and ZUIN \& QUEIROZ (2006).

\section{CONCLUSION}

The existence of a relationship of $\mathrm{MO}$ and II and of SA and II, reinforce the need for rural business actively seek for support of usual agents which interacts to perform the activities of II. While SA directly measure the action of each of these agents in innovation, MO measures the way in which the rural business manages information from customers, suppliers and competitors for their decision making. Rural business search RI through proactive attitudes and greater risk. Probably this attitude comes more of an inner conviction, than those offered for their relationship with external agents, since there is no significant link between SA and RI, or GA and RI, as well as there is no a manifestation of attitude to continuous improvement of MO in relation to RI. There is a lack of relationship between public agencies and universities in support to agricultural activities, indicated by GA with II and RI. This result may be due to the focus provided by these agents in offering more in the transmission of administrative and regulatory information, than in dealing with the business innovation and improving the competitiveness of rural business.

\section{ACKNOWLEDGEMENTS}

To the staff of Fundação de Apoio ao Desenvolvimento do Ensino, Ciência e Tecnologia do Estado de Mato Grosso do Sul (FUNDECT) and Fundação Manoel de Barros (FMB), for the financial support, and to the Universidade Anhanguera Uniderp (UNIDERP) and the Universidad de Salamanca, Spain, for the assignment of researchers and facilities.

\section{BIOETHICS AND BIOSSECURITY COMMITTEE APPROVAL}

The questionnaire was also examined and approved by the Ethics Committee for Human Beings (Protocol no 440 909, of September 16, 2013).

\section{REFERENCES}

BRUGNARO, R.; BACHA, C.J. Análise da participação da agropecuária no PIB do Brasil de 1986 a 2004. Estudos Econômicos, v.39, n.1, p.127-159, 2009.

Ciência Rural, v.46, n.10, out, 2016. 
CEPEA. Relatório PIBAgro-Brasil Janeiro de 2015. Piracicaba: CEPEA/Esalq/USP, 2015., 17 p.

COVIN, J.G.; SLEVIN, D.P. A conceptual model of entrepreneurship as firm behaviour. Entrepreneurship Theory and Practice, v.16, n.1, p.7-25, 1991.

GELLYNCK, $\mathrm{X}$. et al. Association between innovative entrepreneurial orientation, absorptive capacity, and farm business performance. Agribusiness, v.31, n.1, p.91-106, 2015.

HAIR, J.F. et al. A primer on partial least squares structural equation modeling (PLS-SEM). Los Angeles: Sage, 2014. 307 p.

HUNTER, M. A typology of entrepreneurial opportunity. Economics, Management, and Financial Markets, v.8, n.2, p.128-166, 2013.

IBGE. Censo Agropecuário 2006: Brasil, Grandes Regiões e Unidades da Federação. Rio de Janeiro: IBGE, 2009. 758 p.

JOHANNESSEN, J.A. et al. Innovation as newness: what is new, and new to whom? European Journal of Innovation Management, v.4, n.1, p.20-31, 2001.

JOHNSON, A.J. et al. Market orientation, innovatiness, and performance of food companies. Journal of Agribusiness, v.27, n.1/2, p.85-106, 2009.

KUMAR, V. et al. Is market orientation a source of sustainable competitive advantage or simply the cost of competing? Journal of Marketing, v.75, n.1, p.16-30, 2011.
NAMAN, J.L.; SLEVIN, D.P. Entrepreneurship and the concept of fit: a model and empirical tests. Strategic Management Journal, v.14, n.1, p.137-154, 1993.

NARVER, J.C.; SLATER, S.F. The effect of market orientation on business profibility. Journal of Marketing, v.54, n.4, p.20-35, 1990.

RAUCH, A. et al. Entrepreneurial orientation and business performance: an assessment of past research and suggestions for the future. Entrepreneurship Theory and Practice, v.34, n.5, p.761-787, 2009

RUVIARO, C.F. et al. Market-oriented cattle tracebility in Brazilian Legal Amazon. Land Use Policy, v.38, p.104-110, 2014.

SLATER, S.F.; NARVER, J.C. The Positive effect of a market orientation on business profitability: a balanced replication. Journal of Business Research, v.48, n.2, p.69-73, 2000.

TIDD, J.; BESSANT, J. Managing innovation: integrating technological, market and organizational change. Chichester: John Wiley and Sons, 2009. $638 \mathrm{p}$.

VALLE, S.; VÁQUEZ, P. Inclusión de los provedores en el proceso de desarrollo de nuevos productos: un análisis de la industria española. Universia Business Review, v.24, p.62-74, 2009.

ZUIN, L.F.; QUEIROZ, T.R. Agronegócios: gestão e inovação. São Paulo: Saraiva, 2006. 436 p.

WANG, C.L.; AHMED P.K. The development and validation of the organisational innovativeness construct using confirmatory factor analysis. European Journal of Innovation Management, v.7, n.4, p.303-313, 2004. 